\title{
Food Security Concerns, Climate Change and Sea Level Rise in Coastal Cameroon
}

\author{
Wilfred A. Abia, Comfort A. Onya, Conalius E. Shum, \\ Williette E. Amba, Kareen L. Niba, and Eucharia A. Abia
}

\section{Contents}

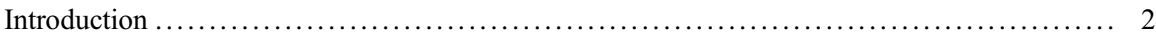

Highlights of Coastal Cameroon .............................................. 3

Coastal Zones and Risk Factors of Agricultural Productivity $\ldots \ldots \ldots \ldots \ldots \ldots \ldots \ldots \ldots \ldots \ldots \ldots$

This chapter was previously published non-open access with exclusive rights reserved by the Publisher. It has been changed retrospectively to open access under a CC BY 4.0 license and the copyright holder is "The Author(s)". For further details, please see the license information at the end of the chapter.

\section{W. A. Abia $(\bowtie)$}

Laboratory of Pharmacology and Toxicology, Department of Biochemistry, Faculty of Science, University of Yaounde 1, Yaounde, Cameroon

School of Agriculture, Environmental Sciences, and Risk Assessment, College of Science, Engineering and Technology (COSET), Institute for Management and Professional Training (IMPT), Yaounde, Cameroon

Integrated Health for All Foundation (IHAF), Yaounde, Cameroon

C. A. Onya

Natural Resources and Environmental Management, University of Buea, Buea, Cameroon

C. E. Shum · W. E. Amba

School of Agriculture, Environmental Sciences, and Risk Assessment, College of Science, Engineering and Technology (COSET), Institute for Management and Professional Training (IMPT), Yaounde, Cameroon

K. L. Niba

School of Agriculture, Environmental Sciences, and Risk Assessment, College of Science, Engineering and Technology (COSET), Institute for Management and Professional Training (IMPT), Yaounde, Cameroon

Integrated Health for All Foundation (IHAF), Yaounde, Cameroon

E. A. Abia

Integrated Health for All Foundation (IHAF), Yaounde, Cameroon 


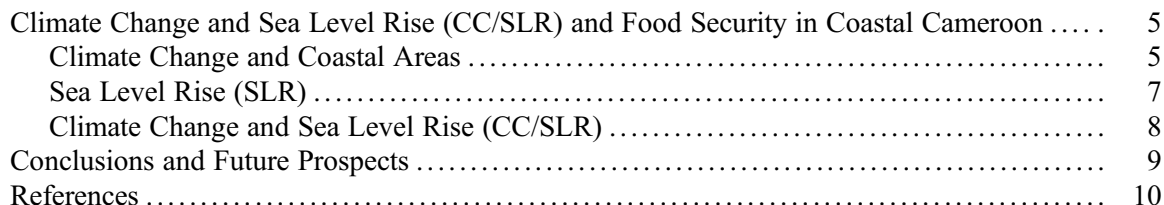

\section{Abstract}

Food security is a major public health priority in Cameroon, amidst climate change and sea level rise (CC/SLR), vis-à-vis the ever-increasing population growth with associated challenges. CC/SLR, singly or combine, is well known to have severe impacts on agricultural productivity, food security, socioeconomic activities and ecosystem (environment, plant and animal) health systems in coastal areas. They contribute to natural disasters including erosion, flooding, inundation of coastal lowlands, and saltwater intrusion, altogether reducing agricultural productivity. Additionally, these disasters provoke adverse animal, human, and environmental health implications; reduction in tourism; and potential close of some socioeconomic activities that constitute secondary (after agriculture), or main source of livelihood/income for many coastal indigents. Although there are inadequate reports on the impacts of CC/SLR, preliminary reports point to negative effects on crop production and socioeconomic activities in coastal Cameroon. This chapter highlights the susceptibility of coastal Cameroon agriculture and socioeconomic activities to CC/SLR. Furthermore, it has propose agricultural (CC/SLR and non-climatic) and educational intervention socioeconomic strategies for the mitigation and adaptation to CC/SLR and for sustainable agricultural productivity in coastal Cameroon. The proposed strategies may provide a small contribution toward a wider multi-stakeholder pool of strategies and which, when applied, may enhance food security in coastal Cameroon amidst CC/SLR and promote socioeconomic and touristic activities while reducing negative implications on animal, plant, human, and environmental health.

\section{Keywords}

Agriculture $\cdot$ Climate change $\cdot$ Sea level rise $\cdot$ Food security $\cdot$ Ecosystem health

\section{Introduction}

Food security is a major concern in feeding the world's estimated 9.8 billion people by 2050 (Worldometer 2020). The demand for food by 2050 will increase by an estimated $60 \%$. This will be associated with broader economic and societal issues. Thus, there is increasing need for sustainable agriculture (Breene 2016; Abia et al. 2016; Center for Development Research (ZEF), Forum for Agricultural Research in Africa (FARA), Institute of Agricultural Research for Development (IRAD) 2017) toward sustainable food supply. Food security exists when all people, at all times, 
have physical and economic access to sufficient safe and nutritious food that meets their dietary needs and food preferences for an active and healthy life (Food and Agriculture Organization (FAO) 2010). In addition, food security has three dimensions. These include (i) availability of food (which consist of three elements related to production, allocation, and exchange); (ii) access to food (that is connected with affordability, e.g., income and wealth, provision, and preferences); and (iii) utilization of food (focusing on the essential elements that are associated with dietetic and social values as well as food safety issues). Additionally, it is vital to ensure that the available and accessible food is safe. Furthermore, food waste should be minimized as much as possible (zero food waste concept. According to the Codex Alimentarius Commission (CAC 2003), food safety is the assurance that food will not cause harm to the consumer when it is prepared and/or eaten according to its intended use.

Food security is generally affected by several factors. Climate change remains one of the most devastating factors. Notwithstanding, both climatic and non-climatic factors, singly and collectively, hinder agricultural productivity. These factors include increase in temperature, fluctuation in rainfall (periods and amounts) and population growth, and sea level rise. Their effects on coastal agricultural productivity and sustainability may be a concern (Schiermeier 2018). They may provoke inundation, soil erosion, and saltwater intrusion (Gopalakrishnan et al. 2019).

In Cameroon, agriculture and food associated sectors provides employment to an estimated $75 \%$ of the adult-working population (mainly small-scale peasant farmers (NIS 2010), contributing 30\% to the gross domestic product (GDP) and account for approximately half of total earnings from exports (DSCN 2002). The sustainability of the agricultural sector in Cameroon is essential (Abia et al. 2016) and sustaining the food sector (ZEF, FARA, IRAD 2017). However, there is inadequate focus on the limitations to the country's coastal agricultural productivity. Coastal Cameroon's agricultural productivity is likely already and may continue to experience adverse impacts of climate change and sea level rise (CC/SLR) especially in terms of area of inundation, soil erosion, flooding, salinity intrusion, and reduction in crop production. This may have serious repercussions on farmers, food security and safety, as well as on the ecosystem (plant, animal and human) health. An early awareness and preparation toward helping coastal farmers cope with CC/SLR is relevant. This chapter highlights the vulnerabilities of coastal Cameroon's agricultural productivity and ecosystem health to CC/SLR induced hazards, with proposed mitigation strategies.

\section{Highlights of Coastal Cameroon}

The coastal lowlands of Cameroon is located between the Atlantic Ocean and the western highlands in the northeast and the south Cameroon plateau in the southeast and covers $402 \mathrm{~km}$ of coastline. The coastal Cameroon spans $15-150 \mathrm{~km}$ inland from the Gulf of Guinea with an average elevation of $90 \mathrm{~m}$. The coastal zone of Cameroon has three sedimentary basins (Campo Kribi, Douala, and Rio-del Rey). These are known to be potentially rich in hydrocarbons and are currently being exploited by 
petroleum companies. The northern part of the coast (including Idenau, Debundscha, Batoke, Bota, and Down Beach) is characterized by a small population size and very few industries and suffering impacts from the volcanic eruptions of Mount Cameroon. For example, during eruption, lava flows obstruct road networks, destroying crops, and induce rise in ocean water thereby killing fishes and other marine ecosystems. The coastal zone harbors the coldest place in Cameroon, Debundscha, which is at the foot of the Mount Cameroon, which experience the highest rainfall (annual average: $11,000 \mathrm{~mm})$. The coastal region is characterized by equatorial climate with less dry ( $\sim 3$ months) and wet ( $\sim 9$ months) seasons alternating. The coastal line has high humidity mainly associated with the Guinea monsoon winds. The center of the coast, i.e., Douala, has an estuarine system of river Wouri and is the part with highest human/anthropogenic activities. Additionally, the central coast has the highest coastal population size and is home to approximately $60 \%$ of Cameroon's industries (Alemagi et al. 2006). It harbors the countries important industrial and environmental interests (Onguéné et al. 2015). The southern coast area (Kribi) harbors the smallest coastal population size and has few industries. The characteristics of coastal Cameroon have been presented variedly e.g., based on water, salt, and nutrient budget of the two estuaries (Gabche and Smith 2002) and based on characteristics of coastal vulnerability to climate change (Leal Filho et al. 2018).

\section{Coastal Zones and Risk Factors of Agricultural Productivity}

Coastal areas are likely to be more vulnerable to climate change than inland areas because, in addition to changes in flooding, temperature, and precipitation, coastal lowlands are frequently affected by sea level rise (SLR) and sea wave heights. Increasing Greenhouse Gas (GHG) emissions may raise the average atmospheric temperature by $1.1{ }^{\circ} \mathrm{C}$ to $6.4{ }^{\circ} \mathrm{C}$ over the next century, with possible thermal expansion of the oceans, rapid melting of ice sheets, and consequently SLR (Intergovernmental Panel on Climate Change (IPCC) 2007a). On the average, the global SLR stood at the rate of $1.8 \mathrm{~mm}$ per year from 1961 to 1993 and at the rate of about $3.1 \mathrm{~mm}$ per year from 1993 to 2003 (IPCC 2007b). Even if GHG emissions were stabilized soon, thermal expansion and deglaciation would continue to trigger SLR for many decades. Furthermore, the continuous growth of GHG emissions and associated global warming could well promote SLR of 1-3 $\mathrm{m}$ in this century, and unexpectedly rapid breakup of the Greenland and West Antarctic ice sheets might produce a $5 \mathrm{~m}$ SLR (Church et al. 2001) and may rise to $7.5 \mathrm{~m}$ by 2020 (Bamber et al. 2019). Altogether, the IPCC Third Assessment Report of 2001 projected a global average SLR of between 20 and $70 \mathrm{~cm}$ between 1990 and 2100 using the full range of IPCC GHG scenarios and a range of climate models (IPCC 2001). Recently, SLR projection until 2030 was reported in the "Special IPCC Report on the Ocean and Cryosphere in a Changing Climate" (IPCC 2019). In the report, two scenarios for GHG emissions are considered: a "low" scenario (known as RCP2.6), with strong reduction of global greenhouse gas emission, such that global warming will probably not exceed $2^{\circ} \mathrm{C}$, and a "high" scenario (referred to as RCP8.5), in which no measures are taken to limit 
GHG emissions. Altogether, it is assumed that the high scenario may lead to SLR of up to $5 \mathrm{~m}$ of the global average sea level in 2030 (IPCC 2019).

Coastal areas are generally vulnerable to anthropogenic influences such as dense population, industrialization, and agricultural activities (Amosu et al. 2012). In the west and central African sub-regions, erosion of beaches is among the major ecological problems (Ibe and Awosika 1991). Due to coastal erosion and SLR, the surface area of the coastal administrative capital of the Gambia, Banjul, may disappear within approximately 50-60 years, thereby jeopardizing livelihood for over 42,000 people (Jallow et al. 1999). SLR causes devastating effects, which could include loss of land, population displacement, loss of economic gain, loss of urban infrastructures and amenities, submersion of agricultural lands, wetlands (or biodiversity) loss, and even the disruption of several ecosystems (Dasgupta et al. 2009).

\section{Climate Change and Sea Level Rise (CC/SLR) and Food Security in Coastal Cameroon}

Combined climate change (e.g., shifting weather patterns) and sea level rise (e.g., increase the risk of catastrophic flooding) (CC/SLR) has continued to threaten global agricultural production, socioeconomic activities and planetary health in an unprecedented manner for a while now, despite continuous efforts world over to mitigate it. There is urgent need for drastic actions, now more than ever; otherwise it will be more complex and expensive adapting to impacts of CC/SLR in the future (United Nations 2019).

SLR is generally referred to as "an increase in the level of the world's oceans due to the effects of global warming." Basically, a warming climate may cause seawater to expand and ice over land to melt. Both scenarios in combination may cause sea levels to rise (SLR). Thus, SLR is one of the major effect of climate change (CC), with rising waters threatening to inundate small-island nations and coastal regions in various parts of the world (Mimura 2013) and Cameroon (Fonteh et al. 2009). The effects of climate change, SLR, and both CC/SLR are discussed below.

\section{Climate Change and Coastal Areas}

Among all the environmental challenges known to have overwhelmed the planet since the $1980 \mathrm{~s}$, it has been estimated that more than $70 \%$ of them are linked to climate change (Lambi and Kometa 2014). In the wake of natural disaster such as droughts, SLR, floods, tropical depressions as hurricanes, storms, and heat waves, there has been an overwhelming negative impact on humankind, the environment, and economic livelihoods (Living with Risk 2002; Associated Program on Flood Management 2009; Brown et al. 2013). Cameroon is exposed to the impacts of climate change particularly her territories located in the Sahelian zone (which are extremely threatened by effects of desertification) and coastal areas (that are highly vulnerable to SLR) (Banseka and Levesque 2018). Partly due to the impacts of 
CC/SLR, coastal Cameroon is already facing extreme weather phenomena such as heavy rainfall, violent winds, high temperatures, and drought, which endanger communities' ecosystems and the services they provide (Molua 2006; Fonteh et al. 2009; Banseka and Levesque 2018).

The major risks of climate change are inundation, soil erosion, and saltwater intrusion (Gopalakrishnan et al. 2019) and which negatively affects agricultural productivity, with the worst impact in the coastal areas. Additionally, it is speculated that by 2080, coastal West Africa may experience a high-risk level of flooding provoked by climate change (Nicholls and Tol 2006).

In addition to the social and human costs, the economic cost of the impacts of climate change is immense. This includes decrease or losses in agricultural productivity due to droughts and increased variability of rainfall due to increased numbers and intensity of natural disasters such as SLR (Banseka and Levesque 2018). It is speculated that, if nothing is done to address climate change, the "cost of inaction" may be huge and is estimated to be between 5\% and $20 \%$ of world GDP, whereas the cost of "acting" is estimated at only $1 \%$ or $2 \%$ (Stern 2006$)$.

In order to contain the devastating effects and or influences of climate change on the environment, agricultural productivity, and ecosystem (animal, human, plant, environmental) health, which has jeopardized the entire planetary systems, two types of policy response measures are needed: mitigation (efforts to limit GHG emission) and adaptation (actions taken to reduce the negative consequences of changes in the climate).

Adaptation capacity designates the ability for society to plan for and respond to change in a way that makes it better equipped to manage its exposure and sensitivity to climate change. Nearly 2.4 billion people (about $40 \%$ of the world's population), live within $100 \mathrm{~km}$ on coastal strip around the globe, making a total of 60 miles of total land surface occupation per/inhabitant of the coastal strip. Thus, oceans coastal and marine resources are very important for people living in coastal communities, which represent $37 \%$ of global population (United Nations Factsheet 2017). The term coastal zone is a region where there is interaction of the sea and land processes, for example, the city of Limbe in the coastal Cameroon.

Globally, the most common adaptation and mitigation measures used is the "Ecosystems Based Adaptation" (EBA) approach. This involves the conservation, sustainable management, and restoration of ecosystems to adapt to the advert effects of climate change (Convention on Biological Diversity (CBD) 2009, 2018). This approach will help people to take into account, manage ecosystems in ways that permit them to adapt to climate change in coastal areas. The United Nations Environmental Program (UNEP) has laid-down foundation guides for EBA options under the UNEP building capacity for coastal EBA for small islands Development States (project funded by European Commission). This guide is a strategic resource geared at helping environmental and adaptation managers and planners, mainly in governmental departments and civil society organizations. It facilitates baselines knowledge and built broad understanding of the principles and concepts of coastal EBA (UNEP 2016). 
In synopsis, "EBA implement and support, environmental decision makers in choosing, implementing, monitoring, evaluating and over time adaptively managing coastal areas." Mangroves, coral reef, estuaries, seagrass beds, dune communities, and other systems on or near shorelines do serve critical ecological functions which are beneficial to human society. Some of these functions include fisheries, storm protection, floods mitigation, erosion control water storage, ground water recharge, pollution abatement, retention, and cycling of nutrients as well as sediments. In a similar manner, the Convention on Biological Diversity (CBA) has also acknowledged and recognized the potential importance of EBA in meeting this challenge (CBD 2009, 2018).

Around the globe, the coastal zone management Act (CZMA) introduced in 1972 is equally applicable. This sought to balance economic development with environmental conservation, mainly by avoiding the scenario of specifying a defensive definition approach to climate change management. The National as well as international CZMA programs encourage various countries of the globe to develop and implement CZMA plans to protect, restore, and develop the resources of their national coastal zones for present and future generations. A good number of states still recognize the importance pre-emptive action to address their vulnerability to climate change (C2ES 2011). Some mitigation innovations include beach nourishment, coastal fortification, and a reactionary approach which includes seawalls, groin and jetty construction, and inshore artificial reefs.

In Cameroon, the reality of climate change is widely acknowledged. It is the consequence of increasing temperatures caused by atmospheric GHGs, altering the functioning of the ecosystems. According to the Fourth Assessment Report of the IPCC, the efficiency is difficult to assess because of natural adaptation and non-climatic factors (IPCC 2007c). Furthermore, 70\% of GHG emissions observed between 1970 and 2004 was caused by human activities (IPCC 2007a). The IPCC Synthesis Report suggests that a continuation of the present policies to mitigate climate change would probably lead GHG emissions to further in the coming decades (IPCC 2007d). Therefore, for improved and sustainable agricultural production, there is a need for continuous monitoring and forecasting and use of crops and varieties that are more resistant to drought and adaptation of suitable planting methods (Molua 2006). Furthermore, there is need for expansion of farm size, livelihood diversification, and usage of organic fertilizers as potential adaptation options (Epule and Bryant 2016). However, non-climatic factors such as deforestation, poor governance, inadequate access to farm inputs (e.g., fertilizers, increased economic opportunities elsewhere and a breakdown of cultural practices) cannot be minimized (Epule and Bryant 2016).

\section{Sea Level Rise (SLR)}

The impact of sea level rise (SLR) on developing countries is overwhelming (Dasgupta et al. 2009). The effects will likely be more in coastal lowlands. SLR is expected to pose unique challenges partly due to the resultant saline contamination. 
SLR may provoke more salt in soils and too much salt in soil can ruin crop yield (e.g., through restriction of water and nutrient uptake by the plant) and render farmlands or fields useless (Schiermeier 2018). SLR in coastal zones could potentially lead to land loss through inundation, erosion of coastal lands, increased frequency and extent of storm-related flooding, and increased salinity in estuaries and coastal freshwater aquifers (Gopalakrishnan et al. 2019).

Fonteh et al. (2009) have revealed possible implications of future SLR on the ecosystems and economic activities along the coast of Cameroon using mapping and valuation approaches. This was partly associated with the high ecological and economic value of the area. It was speculated that an estimated $112-1216 \mathrm{~km}^{2}$ $(1.2-12.6 \%)$ of the coastal area is likely to be lost from a $2-10 \mathrm{~m}$ (equivalent to a low scenario by 2050 and high scenario by 2100) flooding, respectively. Furthermore, approximately between $0.3 \%$ and $6.3 \%$ of ecosystems (estimated to worth US\$ 12.13 billion/year) could be at risk of flooding by the years 2050 and 2100 . The areas under a serious threat contain mangroves, sea and airport, residential and industrial areas, and to a lesser extent, main plantation crops of banana and palms (Fonteh et al. 2009). Although there is inadequate information on the consequences, it may be speculated that this may have adverse effects on coastal agriculture production and may be a threat to food security and safety, as well as on the socioeconomy of the coastal Cameroon. Wetland losses and loss of productive mangrove ecosystem will also occur with a SLR. According to the TOPEX/Poseidon and Jason satellite data, the rate of SLR in Cameroon is 2-2.4 mm/year between 1993 and 2004 (NASA 2008). Thus, the low-lying coastal areas are physically and socioeconomically vulnerable to impacts of SLR. There is need to take prompt actions toward mitigating the effects of SLR provoked natural disasters in coastal Cameroon (Fonteh et al. 2009).

\section{Climate Change and Sea Level Rise (CC/SLR)}

Climate change and sea level rise (CC/SLR) are not new concepts, even though their synergistic effects seem minimized and less talked about vis-à-vis climate change or food security alone or in combination. SLR is a direct consequence of global climate change. It appears to get worst as population growth increases (Gommes and du Guerny 1998). The CC/SLR constitute a major hindrance to agricultural productivity (Schiermeier 2018; Ogbuabor and Egwuchukwu 2017) and may exert adverse effects on ecosystem health (Nicholls et al. 2011) in coastal areas.

As climate change continues to provoke SLR in coastal Cameroon, inundation of low-lying coastal areas increases continuously and with saltwater, and gradually contaminating the soil. Although rainfall can dissipate these salts, climate change is also increasing the frequency and severity of extreme weather events, including droughts and heat waves. This leads to intensive use of groundwater for drinking and irrigation, which further depletes the water table and allows salt to leach into soil. In some parts of the world, especially low-lying river deltas, local land is sinking (known as subsidence), making sea levels that much higher (Nicholls et al. 2007). 
Thus, even without climate change, coastal areas such as coastal Cameroon would still experience slow relative SLR due to these non-climatic processes and hence increased flooding and damage cost through time (Nicholls 2002; Nicholls et al. 2007, 2011).

In addition to adverse impact on agricultural productivity, CC/SLR constitute a nuisance in coastal ecosystem health and socioeconomic activities. This is particularly worse in the developing countries with inadequate capacity to manage associated repercussions on land use, populations' evacuation/displacement and juxtaposition of livelihood sources, i.e., agriculture and touristic activities in the case of coastal Cameroon and elsewhere. For example, in coastal Cameroon, $\mathrm{CC} / \mathrm{SLR}$ may lead to flooding which may provoke internal displacements with associated joblessness. The coastal Cameroon's situation is made worse by the eruption of Mt. Cameroon, which releases lava flow that further reduce agricultural land and destroy crops and marine lives whenever it erupts - a scenario which is arguably by the assumed post eruption increase in soil fertility. Apparently, coastal zones in different geographic areas, with varied anthropogenic activities, non-similar efforts against SLR, and varied effectiveness of erosion-driving forces such as waves and tides, are expected to react differently to SLR. Thus, considering the CC/SLR projected likelihood of high-risk flooding in the lowlands of coastal West Africa (including Cameroon) by 2080 (Nicholls and Tol 2006), there is a need for constant monitoring and timely mitigating actions to salvage coastal Cameroon from the natural disaster. To this effect, we speculate that relevant efforts to mitigate and adapt to CC/SLR may include intensive farmers' education on good agricultural practices, creation of nurseries for improved and climate smart food varieties, irrigation and vertical farming, and a shift from subsistence-to-industrial farming. Application of these strategies may enhance food security, ecosystem health and socioeconomic and touristic activities in the coastal Cameroon.

\section{Conclusions and Future Prospects}

Food security is a major public health priority in Cameroon, vis-à-vis the everincreasing population growth with associated challenges. Risk factors to agricultural productivity such as combined climate change and sea level rise (CC/SLR) require attention, particularly in coastal Cameroon. CC/SLR have negative impacts on agricultural productivity and socioeconomic activities in coastal morphology. This is through its contributions to natural disasters including erosion, flooding, inundation of coastal lowlands, and saltwater intrusion, which all have a significant impact on crop productivity and output. Socioeconomically, these disasters may provoke adverse animal, human, and environmental health implications; reduction in tourism; and potential close of some socioeconomic activities (e.g., beer parlors, and small roadside restaurants) that constitute as secondary (after agriculture), or main source of livelihood/income for many coastal indigents.

Sustainable agricultural productivity in Cameroon is essential, moreover in coastal Cameroon amidst CC/SLR. This requires concerted actions of stakeholders' 
(government, local civil society organizations, individual, and common initiative farmers groups, and international bodies). Such efforts may propose and develop sustainable strategies toward adaptation and mitigation of risk factors of agricultural production and socioeconomic growth in coastal Cameroon. Potential adaptation options may span from agricultural (CC/SLR and non-climatic) to educational intervention socioeconomic strategies. CC/SLR strategies include expansion of farm size, usage of organic fertilizers, creation of nurseries for improved and climate smart crop varieties, irrigation and vertical farming, and a shift from subsistence-toindustrial farming. Non-climatic strategies may include afforestation, good governance, ensuring adequate access to farm inputs (e.g., fertilizers), promotion, and increase of local agribusiness opportunities. Educational intervention socioeconomic strategies may include intensive farmers' education on good agricultural practices, and the diversification of livelihood. These strategies may provide a small contribution toward a wider multi-stakeholder pool of strategies and which, when applied, may enhance food security in coastal Cameroon amidst CC/SLR and promote socioeconomic and touristic activities while reducing negative implications on animal, plant, human, and environmental health.

\section{References}

Abia WA, Shum CE, Fomboh RN, Ntungwe EN, Ageh MT (2016) Agriculture in Cameroon: proposed strategies to sustain productivity. Int J Res Agric Food Sci 2(2):1-12

Alemagi D, Oben PM, Ertel J (2006) Mitigating industrial pollution along the Atlantic coast of Cameroon: an overview of government efforts. Environmentalist 26:41-50

Amosu AO, Bashorun OW, Babalola OO, Olowu RA, Togunde KA (2012) Impact of climate change and anthropogenic activities on renewable coastal resources and biodiversity in Nigeria. J Ecol Nat Environ 4(8):201-211

Associated Program on Flood Management (2009) Integrated flood management concept paper. Flood management policy series (World Meteorological Organization, WMO) No. 1047. Available online at: http://www.apfm.info/pdf/concept_paper_e.pdf. Accessed 20 June 2020

Bamber JL, Oppenheimer M, Kopp RE, Aspinall WP, Cooke RM (2019) Ice sheet contributions to future sea-level rise from structured expert judgment. PNAS 116(23):11195-11200. https://doi. org/10.1073/pnas.1817205116

Banseka H, Levesque LCT (2018) Cameroon: preparing the national adaptation plan for climate change (NAPCC) and its investment strategy (\#492). In Gunya KJ, Philip R, Sara Oppenheimer S (eds) GWP global water partnership. Global Water Partnership (GWP), Stockholm, Sweden

Breene K (2016) Food security and why it matters. Formative content. World Economic Forum. Available online at: https://www.weforum.org/agenda/2016/01/food-security-and-why-it-mat ters/. Accessed 22 Mar 2020

Brown C, Meeks R, Ghile Y et al (2013) Is water security necessary? An empirical analysis of the effects of climate hazards on national-level economic growth. Philos Trans R Soc A 371:20120416. https://doi.org/10.1098/rsta.2012.0416

C2ES (Center for Climate and Energy Solutions) (2011) Climate change 101: understanding and responding to global climate change: adaptation. Available online and accessed on 15.08.2020 at 03:20 at: https://www.c2es.org/site/assets/uploads/2017/10/climate101-fullbook.pdf and https://www.c2es.org/document/climate-change-101-understanding-and-responding-to-globalclimate-change/ 
CAC (Codex Alimentarius Committee of the FAO/WHO) (2003) Codex Alimentarius, basic text on food hygiene, 3rd edn. FAO, Rome

Center for Development Research (ZEF), Forum for Agricultural Research in Africa (FARA), Institute of Agricultural Research for Development (IRAD) (2017) Country dossier: innovation for sustainable agricultural growth in Cameroon. Program of accompanying research for agricultural innovation. Center for Development Research, Forum for Agricultural Research in Africa and Institut de Recherche Agricole pour le Development, Bonn/Accra/Yaounde

Church J, Gregory J, Huybrechts P, Kuhn M, Lambeck K, Nhuan M, Qin D, Woodworth P (2001) Changes in sea level. In: Houghton J, Ding Y, Griggs D, Noguer M, van der Linden P, Xiaosu D (eds) Climate change 2001. The scientific basis. Cambridge University Press, Cambridge, pp 639-693

Convention on Biological Diversity (CBD) (2009) Connecting biodiversity and climate change mitigation and adaptation: report of the second ad hoc technical expert group on biodiversity and climate change. Technical series no. 41, Montreal, $126 \mathrm{p}$

Convention on Biological Diversity (CBD) (2018) Decision adopted by the conference of the parties to the convention on biological diversity: 14/5 biodiversity and climate change. $\mathrm{CBD} / \mathrm{COP} / \mathrm{DEC} / 14 / 5$

Dasgupta S, Laplante B, Meisner C et al (2009) The impact of sea level rise on developing countries: a comparative analysis. Clim Chang 93:379-388. https://doi.org/10.1007/s10584008-9499-5

Direction de la Statistique et de la Comptabilité Nationale (DSCN) (2002) Conditions de vie des Populations et Profil de Pauvreté au Cameroun en 2001: Premiers resultats. Direction de la Statistique et de la Comptabilité Nationale, Yaoundé

Epule ET, Bryant RC (2016) Small scale farmers' indigenous agricultural adaptation options in the face of declining or stagnant crop yields in the Fako and meme divisions of Cameroon. Agriculture 6(2):22. https://doi.org/10.3390/agriculture6020022. Academic Editors: Annelie Holzkämper and Sibylle Stöckli (Special Issue Options for Agricultural Adaptation to Climate Change)

FAO (2010) The state of food insecurity in the world. Food and Agriculture Organization of the United Nations, Rome

Fonteh M, Esteves LS, Gehrels WR (2009) Mapping and valuation of ecosystems and economic activities along the coast of Cameroon: implications of future sea level rise. Int Approaches Coast Res Theory Pract Coastline Rep 13:47-63

Gabche CE, Smith VS (2002) Water, salts and nutrient budgets of two estuaries in the coastal zone of Cameroon. West Afr J Appl Ecol 3:69-89

Gommes R, du Guerny J (1998) Potential impacts of sea-level rise on populations and agriculture. Climate change in Food and Agriculture Organization of the United Nations. Available online at: http://www.fao.org/nr/climpag/pub/EIre0045_en.asp. Accessed 16 Mar 2020

Gopalakrishnan T, Hasan MK, Haque ATMS, Jayasinghe SL, Kumar L (2019) Sustainability of coastal agriculture under climate change. Sustainability 11:7200. https://doi.org/10.3390/ su11247200

Ibe AC, Awosika LF (1991) Sea level rise impact on African coastal zones. In: Omide SH, Juma C (eds) A change in the weather: African perspectives on climate change. African Centre for Technology Studies, Nairobi, pp 105-112

Intergovernmental Panel on Climate Change (IPCC) (2001) Climate change 2001: the physical science basis. In: Houghton JT, Ding Y, Griggs DJ, Noguer M, van der Linden PJ, Xiaosu D (eds) Working group 1 contribution to the third assessment report of the Intergovernmental Panel on Climate Change (IPCC). Global Water Partnership (GWP), Stockholm, Sweden

Intergovernmental Panel on Climate Change (IPCC) (2007a) Climate change 2007 - mitigation of climate change contribution of working group iii to the fourth assessment report of the IPCC (978 0521 88011-4 Hardback; 9780521 70598-1 Paperback) 
Intergovernmental Panel on Climate Change (IPCC) (2007b) Climate change 2007 - the physical science basis contribution of working group I to the fourth assessment report of the IPCC (ISBN 9780521 88009-1 Hardback; 9780521 70596-7 Paperback)

Intergovernmental Panel on Climate Change (IPCC) (2007c) Climate change 2007 - impacts, adaptation and vulnerability contribution of working group II to the fourth assessment report of the IPCC (978 $052188010-7$ hardback; 9780521 70597-4 paperback)

Intergovernmental Panel on Climate Change (IPCC) (2007d) Climate change 2007: synthesis report. In: Core Writing Team, Pachauri RK, Reisinger A (eds) Contribution of working groups I, II and III to the fourth assessment report of the intergovernmental panel on climate change. Global Water Partnership (GWP), Stockholm, Sweden

Intergovernmental Panel on Climate Change (IPCC) (2019) Special report on the ocean and cryosphere in a changing climate. In: Pörtner H-O, Roberts DC, Masson-Delmotte V, Zhai P, Tignor M, Poloczanska E, Mintenbeck K, Nicolai M, Okem A, Petzold J, Rama B, Weyer N (eds). In press. https://www.ipcc.ch/srocc/cite-report/

Jallow BP, Toure S, Barrow MMK, Mathieu AA (1999) Coastal zone of the Gambia and the Abidjan region in Cote d'Ivoire: sea level rise vulnerability, response strategies, and adaptation options. Clim Res 12(2):129-136. https://doi.org/10.3354/cr012129

Lambi CM, Kometa SS (2014) Climate change in Cameroon and its impacts on agriculture. In: Albrecht E, Schmidt M, Mißler-Behr M, Spyra S (eds) Implementing adaptation strategies by legal, economic and planning instruments on climate change. Environmental protection in the European Union, vol 4. Springer, Berlin/Heidelberg

Leal Filho W, F M, Nagy GJ et al (2018) Fostering coastal resilience to climate change vulnerability in Bangladesh, Brazil, Cameroon and Uruguay: a cross-country comparison. Mitig Adapt Strateg Glob Chang 23:579-602. https://doi.org/10.1007/s11027-017-9750-3

Living with Risk (2002) A global review of disaster reduction initiatives. International Strategy for Disaster Reduction (ISDR), Geneva. Accessed at: http://helid.digicollection.org/en/d/Js2653e/

Mimura N (2013) Sea-level rise caused by climate change and its implications for society. Proc Jpn Acad Ser B Phys Biol Sci 89:281-301

Molua EL (2006) Climatic trends in Cameroon: implications for agricultural management. Clim Res 30:255-262. https://doi.org/10.3354/cr030255

National Aeronautics and Space Administration (NASA) (2008) Ocean surface topography from space. Californian Institute of Technology: Jet Propulsion Laboratory, Pasadena, California

National Institute of Statistics (NIS) (2010) The population of Cameroon: reports of the presentation of the final results of the 3rd general census of population and habitats (RGPH): Central Bureau of Census and Population Studies. National Institute of Statistics, Ministry of the Economy and Finance, Yaounde

Nicholls RJ (2002) Analysis of global impacts of sea-level rise: a case study of flooding. Phys Chem Earth Parts A/B/C 27(32):1455-1466. https://doi.org/10.1016/S1474-7065(02)00090-6

Nicholls RJ, Tol RSJ (2006) Impacts and responses to sea-level rise: a global analysis of the SRES scenarios over the twenty-first century. Philos Trans R Soc A 364:1073-1095

Nicholls RJ, Wong PP, Burkett VR, Codignotto JO, Hay JE, McLean RF, Ragoonaden S, Woodroffe CD (2007) Coastal systems and low-lying areas. In: Parry ML, Canziani OF, Palutikof JP, van der Linden PJ, Hanson CE (eds) Climate change 2007: impacts, adaptation and vulnerability. Contribution of working group II to the fourth assessment report of the intergovernmental panel on climate change. Cambridge University Press, Cambridge, UK, pp 315-357

Nicholls RJ, Marinova N, Lowe JA, Brown S, Vellinga P, de Gusmão D, Hinkel J, Tol RSJ (2011) Sea-level rise and its possible impacts given a 'beyond $4{ }^{\circ} \mathrm{C}$ world' in the twenty-first centuryPhil. Philos Trans R Soc A 369:161-181. https://doi.org/10.1098/rsta.2010.0291

Ogbuabor JE, Egwuchukwu EI (2017) The impact of climate change on the nigerian economy. Int J Energy Econ Policy, Econjournals 7(2):217-223.

Onguéné RE, Pemha E, Lyard F, Penhoat Y, Nkoue G, Duhaut T, Ebénézer N, Marsaleix P, Mbiake R, Jombe S, Allain D (2015) Overview of tide characteristics in Cameroon coastal 
areas using recent observations. Open J Mar Sci 05(1):81-98. https://doi.org/10.4236/ ojms.2015.51008

Schiermeier Q (2018) Droughts, heatwaves and floods: how to tell when climate change is to blame. Nature 560:20-22

Stern N (2006) The economics of climate change. Cabinet office - HM treasury. Cambridge University Press, London

United Nations (UN) (2019) Climate change - United Nations. Available online at the DRIP POT SHOP: https://www.drippot.ca/blogs/climate-change-united/climate-change-united-nations. Accessed 16 Mar 2020

United Nations Environmental Program (UNEP) (2016) Options for ecosystem-based adaptation (EBA) in coastal environments: a guide for environmental managers and planners. UNEP, Nairobi

Worldometer (2020) Africa population forecast. Source: Worldometer (www.Worldometers.info). Available online and consulted on 07 Mar 2020 at: https://www.worldometers.info/worldpopulation/africa-population/

Open Access This chapter is licensed under the terms of the Creative Commons Attribution 4.0 International License (http://creativecommons.org/licenses/by/4.0/), which permits use, sharing, adaptation, distribution and reproduction in any medium or format, as long as you give appropriate credit to the original author(s) and the source, provide a link to the Creative Commons license and indicate if changes were made.

The images or other third party material in this chapter are included in the chapter's Creative Commons license, unless indicated otherwise in a credit line to the material. If material is not included in the chapter's Creative Commons license and your intended use is not permitted by statutory regulation or exceeds the permitted use, you will need to obtain permission directly from the copyright holder.

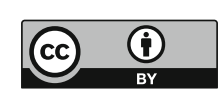

